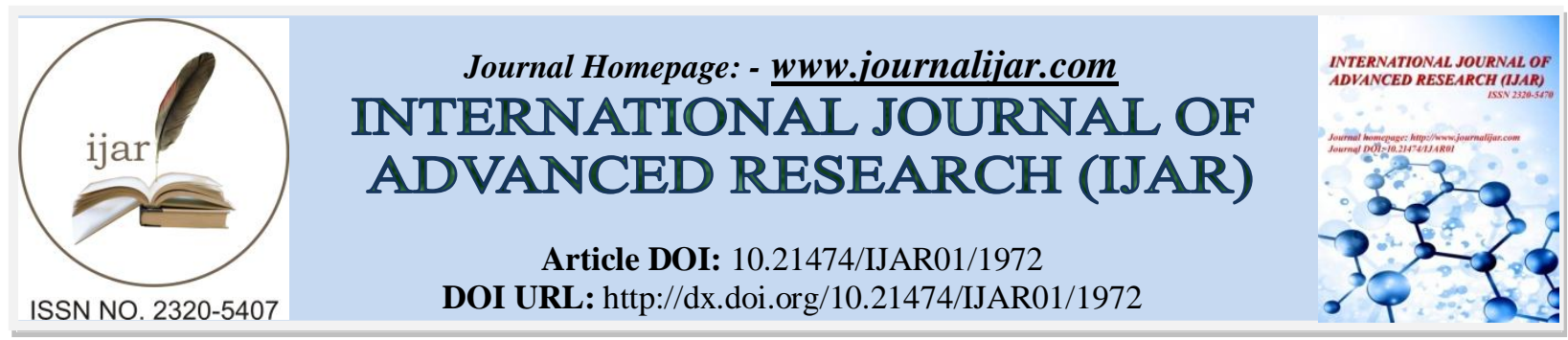

RESEARCH ARTICLE

\title{
EVALUATING STRENGTH OF CONCRETE MIX (M20) USING FLY ASH AND SUGARCANE BAGASSE ASH.
}

\section{Indrajeet Singh Chouhan ${ }^{1}$, Hemant Kumar ${ }^{1}$ and Dr. A. K. Jain ${ }^{2}$}

1. M. Tech. Scholar, Department of Civil and Environmental Engineering, National Institute of Technical Teachers Training and Research, Bhopal (M.P.) India

2. Professor \& Head, Department of Civil and Environmental Engineering, National Institute of Technical Teachers Training and Research, Bhopal (M.P.) India

\section{Manuscript Info}

Manuscript History

Received: 12 August 2016

Final Accepted: 22 September 2016

Published: October 2016

\section{Key words:-}

Sugarcane Bagasse Ash, OPC,

Compressive Strength, Fly Ash, Partial

Replacement

\section{Abstract}

Due to increasing demand and consumption of cement, researchers are in search of alternate binding materials that are eco-friendly and contribute towards waste management. The utilization of industrial and agricultural waste has been focus on reducing waste. This paper presents the effect of sugarcane bagasse ash and fly ash on the properties of concrete. In this research work cement is partially replaced by SCBA and fly ash at $2 \%, 3 \%, 4 \%, 6 \%, 8 \%$, and $12 \%$ by weight of cement. The grade of concrete is M20 and water to cement ratio is 0.5 . The properties for fresh concrete are tested like workability and for harden concrete compressive strength at 7, 14, and 28 days of curing. The tests results indicated that the strength of concrete increases up to $8 \%$ SCBA and fly ash replacement with cement.

Copy Right, IJAR, 2016,. All rights reserved.

\section{Introduction:-}

Use of waste material in concrete is important for environmental aspect. A Good way to the problem of recycling agro industrial excess would be by burning them in a controlled environment use the ashes for useful purpose. Today fly ash and sugarcane bagasse ash is available in large quantities. The production of Portland cement is not only costly and energy intensive but also produces large amounts of carbon emission which is harmful for the environment. The production of one ton of Portland cement produces one ton of carbon dioxide. India is ranked second in major sugar producing countries after Brazil. Sugarcane production in India is 300 million tons leaving 10 million tons of waste. Industrial wastes such as fly ash, sugarcane bagasse ash, rice husk are used as supplementary cement replacement material. Portland cement industry is investigating alternatives to produce green building so use of sugarcane bagasse ash and fly ash is a good solution. With the increasing demand and consumption of cement, researchers and scientists are in search of developing alternate binders that are eco-friendly and contribute towards waste management. When sugarcane bagasse waste is burned under controlled conditions, it gives ash having amorphous silica which has pozzolanic properties. Therefore it is possible to use sugarcane bagasse ash as cement replacing material to improve quality and reduce the cost of construction materials such as mortar, concrete pavers, and concrete roof tile. Bagasse ash imparts high early strength and also reduces the permeability of concrete. Fly ash is a byproduct of the combustion of pulverized coal and is collected by mechanical and electrostatic separators from

Corresponding Author:- Indrajeet Singh Chouhan.

Address:- M. Tech. Scholar, Department of Civil and Environmental Engineering, National Institute of 1625 Technical Teachers Training and Research, Bhopal (M.P.) India. 
the fuel gases of thermal power plants, where coal is used as a fuel. Fly ash improves the workability of plastic concrete, decreased water demand; reduce heat of hydration of cement, improved durability etc.

\section{Material Details:-}

\section{Cement:-}

In the present research work Ordinary Portland cement 53 grade of Ultra Tech cement brand conforming IS: 122691987 is used.

\section{Fine Aggregate:-}

The aggregate size is lesser than $4.75 \mathrm{~mm}$ is considered as fine aggregate. Generally locally available clean natural river sand is used. In the present study sand conforms to zone II as per Indian standards. The specific gravity of sand is 2.63 . The bulk density of fine aggregate is 1715 .

\section{Coarse aggregate:-}

In this study crushed aggregate of $20 \mathrm{~mm}$ maximum size and $10 \mathrm{~mm}$ minimum size is used. The specific gravity of coarse aggregate is 2.66 , the bulk density of coarse aggregate is 1472 .

\section{Fly Ash:-}

Fly ash is one of the residues generated by coal combustion and is composed of the fine particles that are driven out of the boiler with the flue gases. Fly ash particles are irregular to spherical in shape; their diameters range between $0.5 \mathrm{~m}$ to $150 \mathrm{~m}$. of fly ash was collected from HEG Limited Mandideep, Bhopal, Madhya Pradesh. (Fig. 1)

\section{Sugarcane Bagasse:-}

Sugarcane bagasse ash is the waste product of sugar industries produced after combustion of sugarcane bagasse for energy. Sugarcane Bagasse ash contains high volume $\mathrm{SiO}_{2}$. Therefore, it is classified as a good pozzolanic material. In this experimental work SCBA was collected from the Jawaharlal Nehru Sahakari Agricultural Produce Processing Society Limited near Sarvar deola, Borawan, Kasarawad, Khargone, Madhya Pradesh, India. (Fig. 2)

\section{Water:-}

Water available in the college campus confirming to the requirement of water for concreting and curing as per IS: 456-2000.

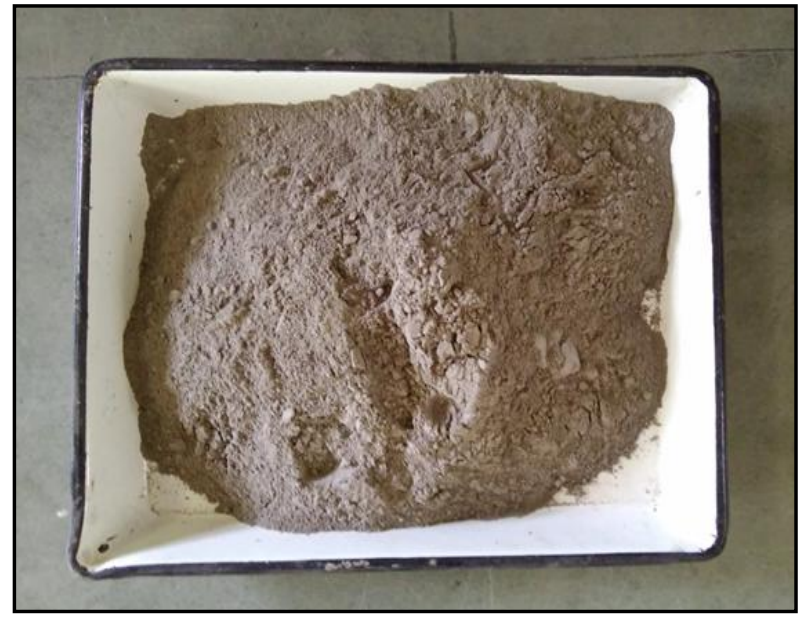

Figure 1:- Fly Ash

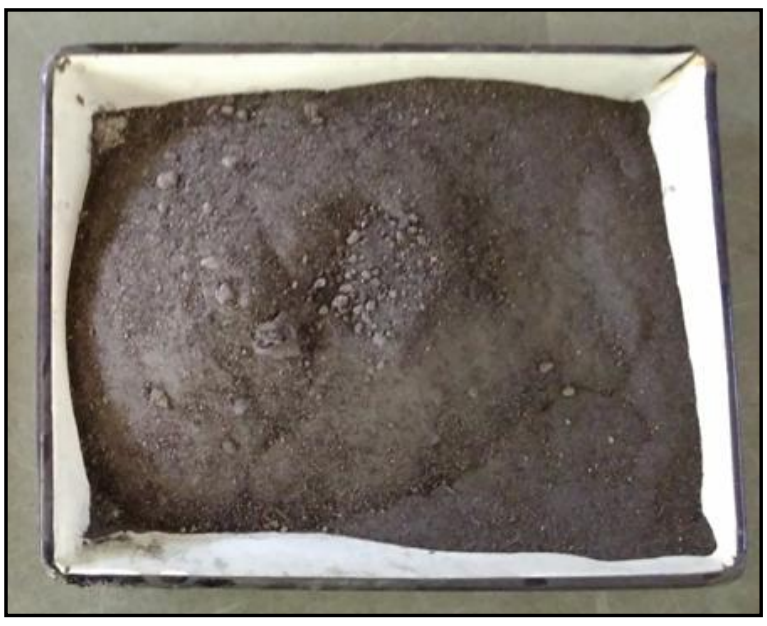

Figure 2:- Sugarcane Bagasse Ash.

\section{SCBA \& Fly Ash Preparation:-}

Before the use of sugar cane bagasse ash and fly ash, it was oven dried at $110^{\circ} \mathrm{C}$ to remove the moisture in the ash. After that ash was sieved to remove un-burnt particles from ash. SCBA and fly ash passing from 90micron was used in this experimental work. 


\section{Mix Design:-}

The mix proportion for M20 grade concrete used in this experiment are carried out according to IS: 10262-1982. The mix proportion obtained and the quantity of materials required for one cube of concrete is given in Table 1. Concrete mixtures were prepared with different proportion of fly ash and SCBA. The proportion (by weight) of fly ash and SCBA added to the concrete mixture were as follows- $0 \%, 2 \%, 3 \%, 4 \%, 6 \%, 8 \%$ and $12 \%$. The water to cement ratio is taken 0.5

Table 1:- Mix Proportion for M20 Concrete.

\begin{tabular}{|c|c|c|c|c|c|}
\hline \multirow{2}{*}{$\begin{array}{c}\text { Replacement of } \\
\text { cement }(\%)\end{array}$} & $\begin{array}{c}\text { Cement } \\
(\mathbf{k g})\end{array}$ & $\begin{array}{c}\text { SCBA } \\
(\mathbf{k g})\end{array}$ & $\begin{array}{c}\text { Fly Ash } \\
\mathbf{( k g )}\end{array}$ & $\begin{array}{c}\text { Sand } \\
(\mathbf{k g})\end{array}$ & $\begin{array}{c}\text { Aggregate } \\
(\mathbf{k g})\end{array}$ \\
\cline { 2 - 6 } & 1.540 & 0.00 & 0.00 & 2.50 & 5.016 \\
\hline 0 & 1.509 & 0.0154 & 0.0154 & 2.50 & 5.016 \\
\hline 2 & 1.493 & 0.0231 & 0.0231 & 2.50 & 5.016 \\
\hline 3 & 1.478 & 0.0308 & 0.0308 & 2.50 & 5.016 \\
\hline 4 & 1.447 & 0.0462 & 0.0462 & 2.50 & 5.016 \\
\hline 6 & 1.416 & 0.0616 & 0.0616 & 2.50 & 5.016 \\
\hline 8 & 1.335 & 0.0924 & 0.0924 & 2.50 & 5.016 \\
\hline 12 & \multicolumn{5}{|l|}{} \\
\hline \multicolumn{7}{|l|}{ Water to Cement Ratio- 0.5 }
\end{tabular}

\section{Experimental Results:- \\ Workability:-}

A high quality concrete is one which has acceptable workability in the fresh condition and develops sufficient strength. The results show that as the amount of sugar cane bagasse ash increases the workability of fresh concrete decreases as compared to the control mix. The results of workability test of concrete with different percentage replacement of cement are given in Table 2 and graphically shown in Figure 4.

\section{Compressive Strength:-}

Total 63 cubes of size 150x150x150mm were casted. The specimens were demoulded after 24 hours and submerged under water till the time of curing. Compressive strength test were conducted on samples made at various curing ages. The cube samples of size 150x150x150 mm were prepared and tested at 7, 14 and 28 days of curing in water. Three samples were tested at each curing ages of various replacement percentage of cement. Table 3 shows the compressive strength of the concrete tested and Figure 5 graphically represents the compressive strength of concrete tested. From the test results it can be observed that the compressive strength of SCBA and fly ash concrete mix with $2 \%, 3 \%, 4 \%, 6 \%$ and $8 \%$ cement replacement with SCBA and fly ash were higher than the control mix.

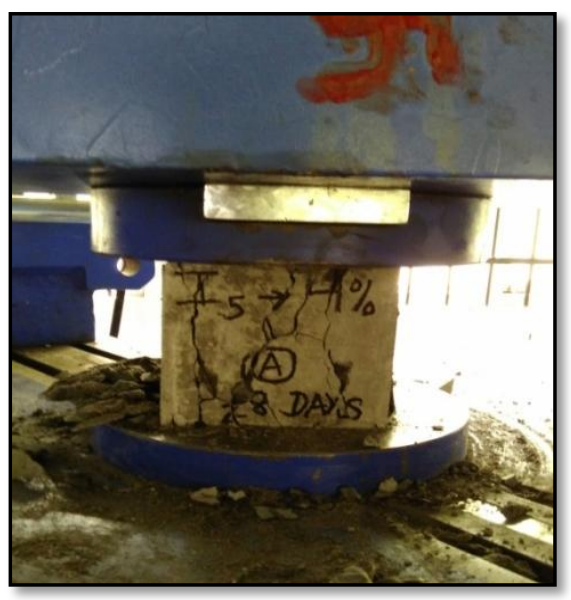

Figure 3:- Compressive Strength Test. 
Table 2:- Workability of Fresh Concrete

\begin{tabular}{|c|c|c|}
\hline S. No. & Replacement of Cement (\%) & Slump Value (mm) \\
\hline 1 & $0-$ Control & 60 \\
\hline 2 & 2 & 50 \\
\hline 3 & 3 & 35 \\
\hline 4 & 4 & 30 \\
\hline 5 & 6 & 25 \\
\hline 6 & 8 & 10 \\
\hline 7 & 12 & \\
\hline
\end{tabular}

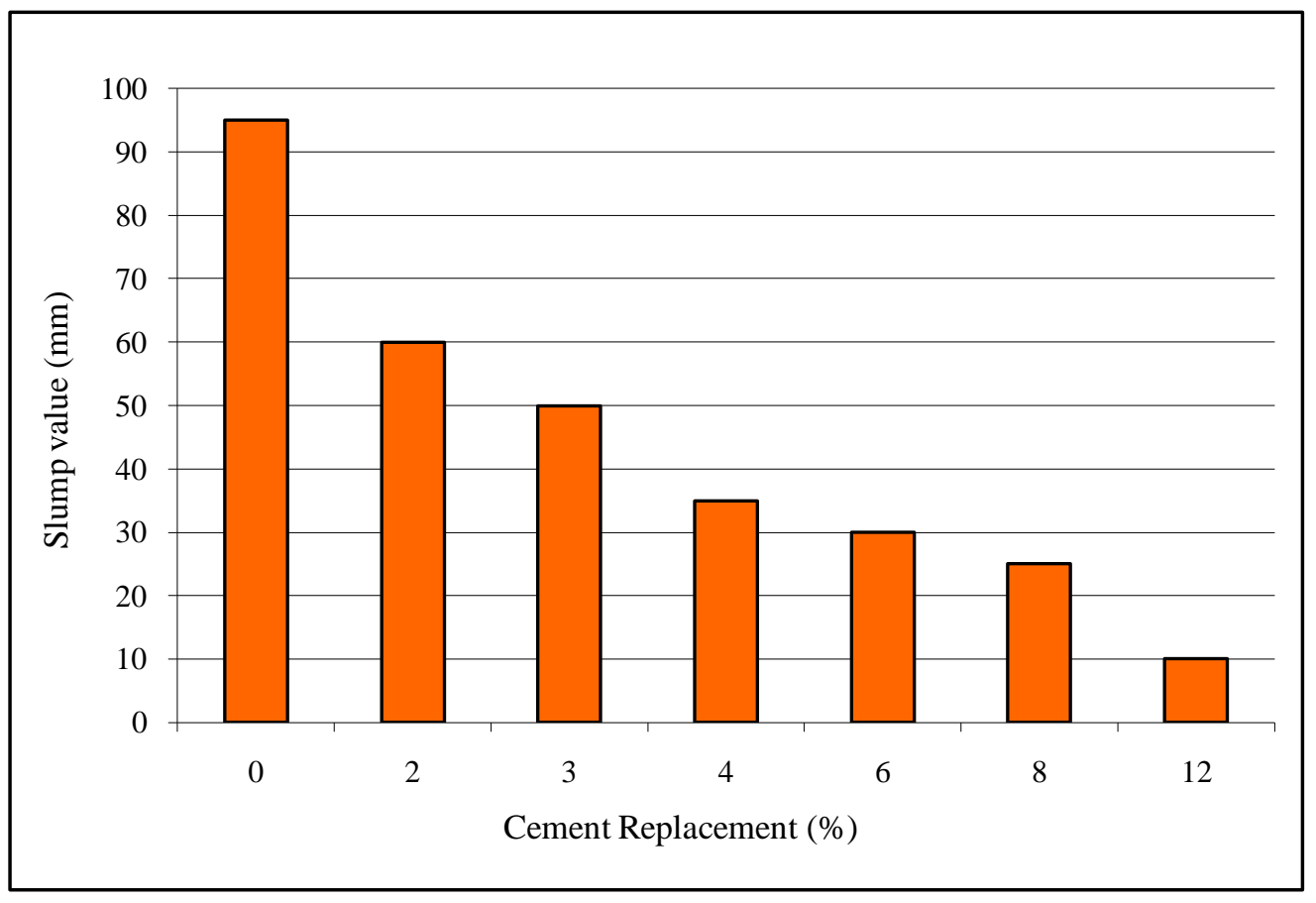

Figure 4:- Slump Values.

Table 3:- Compressive Strength Test Results.

\begin{tabular}{|c|c|c|c|c|}
\hline \multirow[t]{2}{*}{ S. No. } & \multirow{2}{*}{$\begin{array}{l}\text { Replacement of Cement } \\
(\text { SCBA + Fly ash ) (\%) }\end{array}$} & 7 days & 14 days & 28 days \\
\hline & & $\mathrm{N} / \mathrm{mm} 2$ & $\mathrm{~N} / \mathrm{mm} 2$ & $\mathrm{~N} / \mathrm{mm} 2$ \\
\hline 1 & 0- Control & 23.27 & 29.87 & 32.85 \\
\hline 2 & 2 & 34.04 & 36.88 & 40.56 \\
\hline 3 & 3 & 33.55 & 34.64 & 38.10 \\
\hline 4 & 4 & 30.50 & 33.17 & 36.48 \\
\hline 5 & 6 & 29.54 & 33.00 & 36.00 \\
\hline 6 & 8 & 28.28 & 32.17 & 35.38 \\
\hline 7 & 12 & 23.00 & 29.50 & 32.45 \\
\hline
\end{tabular}




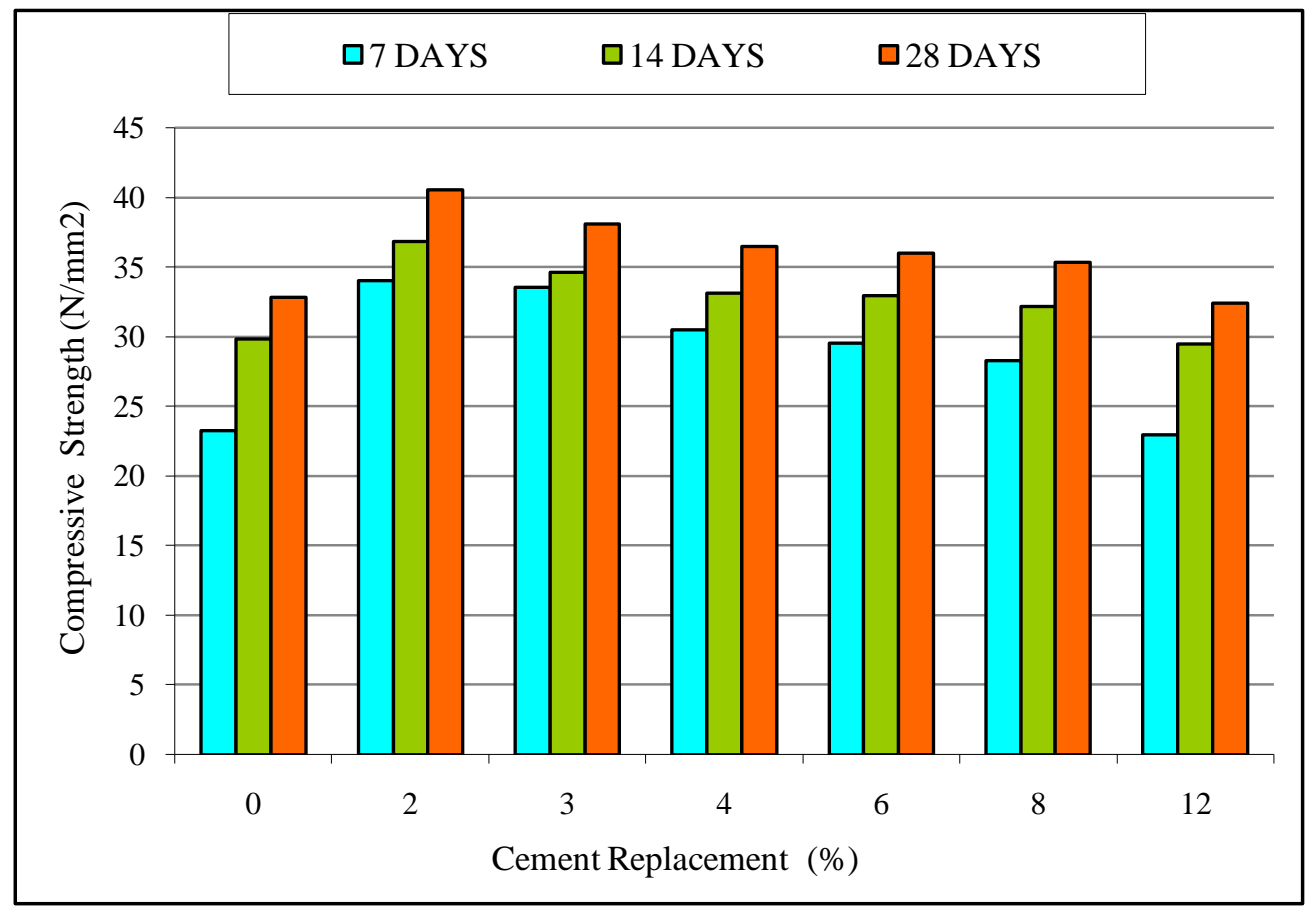

Figure 5:- Compressive Strength Test Results.

\section{Conclusions:-}

The results show that the fly ash and SCBA in blended concrete had significantly higher compressive strength compare to the control mix. It is found that cement can be advantageously replaced with fly ash and sugarcane bagasse ash up to maximum limit of $8 \%$. The workability of concrete goes on decreasing with increase of quantity of fly ash and SCBA in concrete mix. The density of concrete cubes decreases with increase in fly ash and SCBA content. The above results show a beneficial application of the use of SCBA and fly ash, reduce the environment problems and also minimize the requirement of land fill area to dispose SCBA and fly ash.

\section{References:-}

1. R. Srinivasan and K. Sathiya -'Experimental study on bagasse ash in concrete', - International Journal of Service Learning in Engineering, 2010, Vol. 5, Issue 2, pp. 60-66.

2. T. Malyadri and J. Supriya- 'Experimental study on baggasse ash in concrete by partial replacement with cement,' International Journal of computer engineering in research Trends, 2015, Vol. 2, Issue 12, pp. 9951001 .

3. Jayminkumar A. Patel and D. B. Raijiwala- 'Experimental study on use of sugar cane bagasse ash in concrete by partially replacement with cement,' International journal of innovative research in science engineering and technology, 2015, Vol. 4, Issue 4, pp.2228-2232.

4. S. Dharanidharan et al - 'An experimental study on mechanical properties of concrete by using sugar cane bagasse ash,' International Journal of engineering science and technolgyy, 2015, vol. 4(3), pp. 401-405.

5. P.R. Wankhede and V.A. Fulari- 'Effect of fly ash on properties of concrete,' International journal of emerging technology and advance engineering, 2014, vol. 4, Issue 7, pp.284-289.

6. U. R. Kawade et al- 'Effect of use of bagasse ash on strength of concrete,' ' International journal of innovative research in science engineering and technology, 2013, vol. 2 Issue 7, pp. 2997-3000.

7. Aman Jatale et al- 'Effect on compressive strength when cement is partially replaced by fly ash,' IOSR Journal of Mechanical and Civil Engineering, 2013, Vol. 5, Issue 4, pp. 34-43.

8. P. Vipul Naidu and Pawan Kumar- 'Replacement of cement in concrete,' International journal of environmental research and development, 2014, Vol. 4 No. 1, pp. 91-98. 